2000s-20

\title{
Towards an Innovation Intensity Index: The Case of CIS 1 in Denmark and Ireland
}

Pierre Mohnen, Marcel Dagenais

\begin{tabular}{c}
\hline Série Scientifique \\
Scientific Series
\end{tabular}

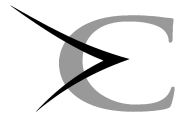

\section{CIRANO}

Centre interuniversitaire de recherche
en analyse des organisations

Montréal

Juin 2000 


\section{CIRANO}

Le CIRANO est un organisme sans but lucratif constitué en vertu de la Loi des compagnies du Québec. Le financement de son infrastructure et de ses activités de recherche provient des cotisations de ses organisationsmembres, d'une subvention d'infrastructure du ministère de la Recherche, de la Science et de la Technologie, de même que des subventions et mandats obtenus par ses équipes de recherche.

CIRANO is a private non-profit organization incorporated under the Québec Companies Act. Its infrastructure and research activities are funded through fees paid by member organizations, an infrastructure grant from the Ministère de la Recherche, de la Science et de la Technologie, and grants and research mandates obtained by its research teams.

\section{Les organisations-partenaires / The Partner Organizations}

-École des Hautes Études Commerciales

-École Polytechnique

-Université Concordia

-Université de Montréal

-Université du Québec à Montréal

-Université Laval

-Université McGill

-MEQ

-MRST

-Alcan Aluminium Ltée

-AXA Canada

-Banque Nationale du Canada

-Banque Royale du Canada

-Bell Québec

-Bombardier

-Bourse de Montréal

-Développement des ressources humaines Canada (DRHC)

-Fédération des caisses populaires Desjardins de Montréal et de l'Ouest-du-Québec

-Hydro-Québec

-Imasco

-Industrie Canada

-Pratt \& Whitney Canada Inc.

-Raymond Chabot Grant Thornton

-Ville de Montréal

(C) 2000 Pierre Mohnen et Marcel Dagenais. Tous droits réservés. All rights reserved.

Reproduction partielle permise avec citation du document source, incluant la notice ().

Short sections may be quoted without explicit permission, provided that full credit, including ( $)$ notice, is given to the source.

Ce document est publié dans l'intention de rendre accessibles les résultats préliminaires de la recherche effectuée au CIRANO, afin de susciter des échanges et des suggestions. Les idées et les opinions émises sont sous l'unique responsabilité des auteurs, et ne représentent pas nécessairement les positions du CIRANO ou de ses partenaires.

This paper presents preliminary research carried out at CIRANO and aims at encouraging discussion and comment. The observations and viewpoints expressed are the sole responsibility of the authors. They do not necessarily represent positions of CIRANO or its partners.

\section{ISSN 1198-8177}




\title{
Towards an Innovation Intensity Index: The Case of CIS 1 in Denmark and Ireland*
}

\author{
Pierre Mohnen ${ }^{\dagger}$, Marcel Dagenais ${ }^{*}$
}

Résumé / Abstract

Cet article a pour objet de construire un indicateur synthétique de l'innovation, qui résulte d'une prédiction économétrique de la probabilité d'innover et du montant d'innovation que fera une firme, conditionnelle à ses caractéristiques et à celles de l'environnement dans lequel elle opère. Cet indicateur se fonde sur différentes informations de nature qualitative et quantitative comprises dans l'enquête innovation. L'indicateur permet de comparer les performances d'innovation entre secteurs, régions ou pays, pour autant que les enquêtes soient suffisamment homogènes. Cet article applique la nouvelle mesure aux données de l'enquête innovation CIS 1 du Danemark et de l'Irlande.

The purpose of this paper is to propose a composite innovation indicator derived from an econometric prediction of the likelihood of innovating and of the amount of innovation performed by a particular firm, given information on its characteristics and on the environment in which it operates. The indicator is constructed from various pieces of information contained in the Community Innovation Surveys. It combines qualitative and quantitative data. It allows the comparison of innovativeness across industries or classes of firms in a particular country. To the extent that the national innovation surveys are sufficiently homogeneous, it also allows comparisons across countries. This paper applies the proposed indicator to the CIS 1 data for Denmark and Ireland.

Mots Clés : Innovation, Tobit généralisé, indicateur

Keywords: Innovation, generalized Tobit, indicator

JEL: O31

\footnotetext{
* Corresponding Author: Pierre Mohnen, CIRANO, 2020 University Street, 25 ${ }^{\text {th }}$ floor, Montréal, Qc, Canada H3A 2A5 Tel.: (514) 985-4028 Fax: (514) 985-4039 email: mohnenp@cirano.umontreal.ca We thank Dominique Guellec for many stimulating discussions. Alfred Kleinknecht, Jacques Mairesse and Jose Labeaga provided helpful comments. We are also grateful for the comments we received when presenting this paper at WZB, CIRANO, OECD, a TSER conference in Delft and a SESSI conference in Paris. We thank Eurostat for giving us permission to use the microaggregated CIS 1 data. Finally, we wish to thank Julio Rosa for his dedicated research assistance.

† Université du Québec à Montréal and CIRANO

* Université de Montréal and CIRANO
} 


\section{Introduction}

Under the guidelines set out in the Oslo Manual (OECD (1992)) and under the coordination of Eurostat, various European countries conducted an innovation survey for the year 1992. The Oslo manual and the Community Innovation Surveys (CIS) grew out of a concern to capture: a) a wider range of innovation activities than R\&D expenditures, such as the acquisition of patents and licenses, product design, personnel training, trial production, and market analysis; b) indicators of innovation output other than patents, such as the introduction of new products, processes and organizational changes, the percentage of sales due to new products, the percentage of sales due to products new to the industry, and the share of products at various stages of the product life-cycle; and c) information about the way innovation proceeds, such as the sources of knowledge, the reasons for innovating, the perceived obstacles to innovation, the perceived strength of various appropriability mechanisms, and the recourse to research cooperation.

The purpose of this paper is to propose a composite innovation indicator derived from an econometric prediction of the likelihood of innovating and of the amount of innovation performed by a particular firm, given information on its characteristics and on the environment in which it operates. The 
indicator is constructed from various pieces of information contained in the Community Innovation Surveys. It combines qualitative and quantitative data. It allows the comparison of innovativeness across industries or classes of firms in a particular country. To the extent that the national innovation surveys are sufficiently homogeneous, it also allows comparisons across countries. As more surveys become available, we can proceed to a comparison of innovation over time. This paper applies the proposed indicator to the CIS 1 data for Denmark and Ireland. The composite indicator is compared to various partial indicators directly contained in the innovation surveys.

The paper is organized as follows. In section 2 we go over the various partial innovation indicators available in CIS 1 and use them to compare innovation records in Denmark and Ireland. In section 3 we discuss the possibility of constructing a single composite innovation indicator. In section 4 we present the model underlying our proposed composite indicator. In section 5 we present the estimation results of our model and compare our composite innovation indicator to the partial innovation indicators. We summarize the main points of the paper in the concluding section. 


\section{Various partial innovation indicators}

The CIS 1 dataset contains a rich amount of data on the input, the output, and the modalities of innovative activities. Some of these data are quantitative, some are dichotomous (yes/no responses), and some are polychotomous, categorically ordered, data (on a scale of 1 to 5 , the so called Likert scale). On the input side, we have quantitative data on R\&D expenditures and on current and capital expenditures on innovation, and dichotomous data on whether firms have engaged or not in $R \& D$, in $R \& D$ collaboration or in acquisition of technology. On the output side, we have the declaration of whether an enterprise has introduced a new product or process, the percentage of sales with respect to incrementally or significantly changed products, the percentage of sales at various stages of the product life-cycle, the sales share of innovative product new to the enterprise/group, and the sales share of innovative products new to the industry. ${ }^{1}$ Innovation and R\&D expenditures are further broken down into products and processes and sales figures

\footnotetext{
${ }^{1}$ The various sales percentages are in principle data on a continuous scale between 0 and 1. They are, however, often reported in round figures. In the French survey, they are simply treated as a categorical variable.
} 
are split into domestic sales and exports. ${ }^{2}$ On the modalities of innovation, we have dichotomous data on whether $\mathrm{R} \& \mathrm{D}$ was done on a continuous basis, and in cooperation with others, and categorical data on information for innovation, the reasons for innovating, the perceived obstacles to innovation, and the perceived strength of various appropriability mechanisms. ${ }^{3}$

Do these various indicators coincide? There are good reasons to think that input and output indicators might differ. First of all, not all firms are equally efficient in turning research efforts into sales, productivity or profits. Secondly, firms may have different ways of innovating. Some rely on their own research, others rely more on research networks or on the outright purchase

\footnotetext{
${ }^{2}$ Other measures of innovation output, not contained in the CIS surveys, are the number of patents (used by Crépon, Duguet and Kabla (1996)), the number of innovation counts (used by Albach et al.(1996)), and the number of new product announcements in trade journals (used by Brouwer and Kleinknecht (1996)). These three indicators are more objective than the self-assessment responses from the innovation surveys, but they suffer from a selection bias due to the firms' own propensity to patent, to declare an innovation, to publish new findings in trade journals, and also due to the patent officer's or the publisher's acceptance of the innovation as worthwhile. Moreover these indicators do not convey any information on the success of an innovation.

${ }^{3}$ For a thorough discussion on the comparison amongst a number of innovation indicators (even beyond those contained in the CIS I surveys), see Kleinknecht (1999).
} 
of ideas. Different structures in the current expenditures on innovation can therefore coexist, just as firms can have different technologies of production. Therefore reliance on $R \& D$ expenditures alone might give a false impression of the comparative innovation efforts or capacities.

These points are illustrated in the following two studies. Baldwin and Gellatly (2000) show that the ranking of Canadian newly born firms in terms of innovation capacity depends on whether one emphasizes technological competencies (e.g. computer-controlled production or use of information technology), innovative competencies (e.g. R\&D, introduction of new products) or human capital skills (e.g. training, skilled personnel). All new firms are strong somewhere. Crépon, Duguet, Kabla (1996) report that only $20 \%$ of the 9871 French manufacturing firms in their sample which did some research in 1989 innovated between 1986 and 1990, whereas only 74 percent of all innovators performed some $R \& D$. These numbers show very clearly the difference between $R \& D$ and innovation.

In spite of this, various studies show that the alternative measures of innovation are correlated to some extent. Crépon, Duguet and Kabla (1996) use the French innovation survey, which covers the period 1986-90, and compare four indicators of innovation: the amount of $R \& D$, the number of patents, 
the dichotomous variable indicating whether or not a firm made a radical innovation, and the share in sales of new products. They find similar sectoral and firm-specific determinants for the four innovation measures, although the explanation is stronger for $R \& D$ than for the share in sales of new products. The four indicators are therefore likely to be correlated. A similar exercise has been done on the Dutch innovation survey data by Brouwer and Kleinknecht (1996). They compare the determinants of new product announcements, of the shares in sales of products new to the firm but not to the industry (imitations), and of the shares in sales of products new to the industry (genuine innovations). They estimate a generalized Tobit model and find that R\&D is correlated with the probability to innovate, whatever the measure of innovation, but not with the level of it, except for imitations. They also find a similar estimated "innovation production model" on the three sets of data. Crépon, Duguet and Mairesse (1998) relate the share of product less than five years old to the stock of R\&D. They estimate an elasticity of the former with respect to the latter of 0.3 on French innovation data.

Before comparing various partial innovation indicators from CIS 1, we want to make a few remarks about the data they contain:

1. We should bear in mind that the data we are working with have been 
micro-aggregated by Eurostat for reasons of confidentiality (Eurostat (1996) explains the micro-aggregation procedure used). On the basis of statistical criteria (such as sample distributions by deciles, variance, Pearson correlation coefficients) Eurostat (1996) concludes that the quality of the micro-aggregation is quite good. However, it admits that the quality is not the same for all variables (because the response rates are higher from some variables than for others) and that the comparability between the original and the micro-aggregated variables deteriorates in the tails of the distributions. In the sequel of the report we shall treat each observation as pertaining to a particular firm.

2. We should also be aware of the inherent limitations of the data. As discussed at great length in Archibugi, Cohendet, Kristensen, and Schäffer (1994), the first round of the Community Innovation Surveys has a number of deficiencies: the national surveys differ regarding sample units, coverage, cut-off points in the number of employees, actual data collection and sampling design. The questionnaire was perceived to be too long, which could explain the low response rates as well as the bad quality of, and inconsistency in, some of the responses. Especially many non-responses were observed for the items "expenditures on inno- 
vation", "sales according to life cycle" and "sales from new or improved products". The international comparability of the CIS data is therefore hazardous. The data are probably better suited for cross-industry comparisons within countries than for cross-country comparisons.

3. There is little information in the dataset regarding non-innovators. Firms are first asked some general questions on their identity, such as their total sales (broken down into domestic sales and exports), their number of employees, their industry affiliation, and their possible belonging to a conglomerate. Then come the three central questions: whether or not they have introduced a new or a changed product, whether they have introduced a new process, and whether they intend to do either one in the near future. If they respond "no" to the three questions, they are only asked for their perception of a list of obstacles to innovation. And that completes the questionnaire. We thus have very little information in the CIS 1 database to discriminate between innovators and non-innovators. In some countries, subject to data accessibility, innovation surveys can be merged with other surveys on the same business units. Access to these data then allows a deeper analysis of the innovation potential for non-innovative firms and a correction for 
selectivity bias in econometric analyses on quantitative data characterizing innovative firms.

We have cleaned the data for outliers, missing values, and inconsistencies. We have eliminated all enterprises with less than 20 employees, with missing industry affiliation, with sales growth from 1990 to 1992 lower than $-40 \%$ and higher than $250 \%$, with $\mathrm{R} \& \mathrm{D} /$ sales ratios positive but lower than $0.1 \%$ or higher than $50 \%$ or with current expenditures on innovations positive but lower than $0.1 \%$ or higher than $100 \%$ of their sales. Table 1 summarizes the outcome of this cleaning exercice.

A first way to ascertain the innovation performance is by way of count data. We can count the percentage of innovating firms, the percentage of innovators with products new to the industry, the percentage of R\&D performers, the percentage of continuous R\&D performers and so on. Table 2 presents some of those count indicators. Of the total number of manufacturing firms in the restricted sample, $65 \%$ of them have innovated in Denmark against $77 \%$ in Ireland. ${ }^{4}$ Two thirds of the innovators (or $42.6 \%$ of all firms in the sample) have introduced a product new to the industry in Denmark.

\footnotetext{
${ }^{4}$ As some firms declare that they have introduced or developed a technologically changed product or process, but do not report any sales of new products, we have been conservative and only considered as innovators those that actually report a share in sales
} 
No information on this variable exists for Ireland. Of all innovating firms in Denmark (Ireland), $82 \%(67 \%)$ are R\&D performers. By the way the questionnaire has been formulated, we have unfortunately no information on the number of R\&D performers who have not innovated. The proportion of innovating firms is generally higher in Ireland than in Denmark. The notable exception is the amalgam of industries 23 and 24 (refined petroleum and chemicals).

A simple count of the number of innovators has, however, a number of drawbacks. First, it does not truly reflect the importance of those innovations. Some are minor product improvements, others relate to a whole new product line. There is not, as patent citations are for patents, a measure that one could use to attach weights to innovations. Some of the responses to the innovation are subjective, based not on a company's accounting data but on the respondent's own judgement (e.g. drastic vs incremental innovation). What is considered to be an innovation for a small firm might not qualify as such for a large firm. Product innovations might be more often declared than process innovations. Second, a cross-sectional comparison of innovation counts is not very meaningful if the industry concentration (the due to new products. 
number of firms per industry), the statistical definition of a firm, and the sample coverage differ.

A second way of measuring innovation is by way of quantitative data on innovation inputs. We have selected two measures: the traditional R\&D expenditures, and the more encompassing concept of current expenditures on innovation. R\&D, as defined in the Frascati manual, is a concept firms should be familiar with since R\&D surveys have been conducted for many years now. Current expenditures on innovation is a new concept, which, as we shall see, firms have evidently not well grasped. It comprises expenditures related to $\mathrm{R} \& \mathrm{D}$, acquisition of patents and licenses, product design, trial production, training and tooling-up, market analysis and others not elsewhere classified. ${ }^{5}$ Few firms, however, run an accounting for innovation expenditures, whereas they often do so for R\&D expenditures if only for claiming tax deductions. The new variable is thus badly measured. It is even often left unanswered. ${ }^{6}$

\footnotetext{
${ }^{5}$ In the 1992 CIS for the Netherlands, for a sample of 8874 firms, Brouwer and Kleinknecht (1997) report that R\&D accounts for $34 \%$ of total innovation expenditures in manufacturing and for $20 \%$ in services. In Italy, R\&D expenses amount to $20 \%$ of innovation costs, in the Nordic countries to 50\% (Archibugi, Cohendet, Kristensen and Schäffer (1995)).

${ }^{6}$ Brouwer and Kleinknecht (1997) have estimated that the probability of giving accurate estimates increases with the $R \& D$ intensity and with the tendency to do $R \& D$ on a
} 
A third way of measuring innovation is to resort to quantitative data on the output of the innovation process, the sales due to new products. Those can be decomposed into sales of incrementally changed and of significantly changed or newly introduced products. We have regrouped the two categories and exploited instead the distinction between sales of products new to the firm but known to the industry and sales of products new to the industry. The former can be assimilated with imitations, the latter with drastic innovations. Two innovations can be of unequal value in terms of sales, exports, or profits. Therefore, it would be best to weight them differently according to their impact on the variable one is interested in. In a way, that is what the sharein-sales indicator does. If an innovation is very successful, it generates a high percentage of sales from new products. A high share may, however, also imply that many new products have been introduced in recent years, some being more successful than others. Strictly speaking, the two output measures pertain to product innovation. We have no measure of the impact of process innovation. However, the firms which declare to be product innovators most of the time also declare to be process innovators. ${ }^{7}$ Auzeby (1996) noticed the continuous basis.

${ }^{7}$ In our sample, there is no occurence of a Danish entreprise doing process innovation without also doing product innovation and only 5 firms do product innovation without 
same with the French innovation survey. It can indeed be argued that a new product generally requires a new production method, while new processes are hard to introduce without changing the products.

In table 3 we compare the four quantitative indicators $(R \& D$, current expenditures on innovation, sales due to changed or new products, and sales of products new to the industry), expressed as percentages of total sales, at the industry level. The figures are sales-weighted averages of individual figures. A better way to aggregate the individual indicators would have been to use value added as weights, value added reflecting more accurately the importance of firms in total activity. Value added is, however, not available from CIS. ${ }^{8}$ The conclusions we draw are not very different if we use employment weights instead of sales weights.

The first thing to notice is the high intensity of $R \& D$ in the innovation sample. An $R \& D /$ sales ratio (even lower than the $R \& D /$ value-added ratio) of $3.5 \%$ for Denmark is inconsistent with the OECD-reported Danish ratio of gross expenditures of business enterprise R\&D over disposable income doing process innovation. In Ireland, the figures are respectively 5 and 3.

${ }^{8}$ We have data on labor in the questionnaire, but no information of labor costs, which could have been used as a proxy for value-added, under the assumption of uniform wages within an industry. 
of $1.3 \%$. Either the innovation sample is biased towards innovators or the respondents declare more $R \& D$ in the innovation survey than in the $R \& D$ survey. The difference is somewhat less pronounced in Ireland..

There is a striking incoherence between the ratio of $R \& D$ over current innovation expenditures that can be computed from the two separate items in the questionnaire and the ratio that is directly reported by the respondents when asked about the R\&D composition of their current expenditures on innovation. In Denmark, the computed ratio is 1.41 for all innovators and the weighted average of the declared ratios is 0.48 . The fact that the former is greater than 1 clearly shows the misunderstanding regarding the definition of the current innovation expenditures. In Ireland, the inconsistency is not so strong, the computed ratio being 0.56 and the declared ratio 0.29 . One possible explanation for this incoherence is that current innovation expenditures and their components were interpreted by the respondents as pertaining only to the costs of current innovations, those that materialized in new products or processes declared elsewhere in the questionnaire, whereas the question on $R \& D$ was understood as pertaining to $R \& D$ as an investment, whether it lead to immediate innovations or not. In some instances, it was crystalclear that the question was interpreted as asking what innovation costs were 
incurred besides R\&D expenses (although the questionnaire clearly defined innovation costs as including R\&D expenses). Moreover, innovation expenditures sometimes referred to product innovations only, sometimes to both product and process innovations, and, for some countries, it was not even clear which definition was really meant. Current expenditures on innovation is thus not a very reliable indicator.

We report the quantitative indicators once with respect to all firms, once with respect to innovating firms only, i.e. the numerators remain the same, only the denominators differ. For all firms in the sample, sales of changed or new products account for $35.5 \%$ of total sales in Denmark and for $31.5 \%$ in Ireland. The figure climbs to a sizeable $47.6 \%$ and $41.0 \%$ respectively for the subsample of innovating firms. The proportion of sales due to products new to the industry represents $12.7 \%$, or roughly one third of innovative sales, in Denmark. For Ireland, this information is not available in CIS 1.The innovation ratios with respect to overall industry sales reflect both the intensity of innovation for innovating firms and the percentage of innovating firms. For instance in textiles and leather (industries 17-19) Danish innovating firms are very innovative in terms of the percentage sales in new products $(79.2 \%)$. If we correct for the fact that only $50 \%$ of the respondents declare to be in- 
novators, the indicator drops to $41.8 \%$. The Irish firms in this industry only have $37.3 \%$ of their sales in new products, but given that a high percentage $(80.9 \%)$ of the respondents declare to be innovators, the industry-wide sales percentage of the new products indicator drops to only $30.3 \%$. We also report statistics on small firms, defined as firms with sales below the median sales figure for the whole sample. Smaller firms are less innovative on almost all counts in Denmark, while in Ireland they score higher in R\&D/output and innovation expenditures/output ratios.

Table 3 illustrates the difficulty of choosing a single innovation indicator and the advantage of using separately the input and output indicators. The two output indicators achieve the highest score for the motor vehicles and other transportation equipment industry (industries 34-35) in Denmark and for the manufacture of machinery and equipment in Ireland (industry 29). These superiorities are not at all reflected in the input indicators. Both countries achieve the highest $R \& D$ intensity, and also the highest intensity in current expenditures on innovation despite the inconsistency, in petroleum refining and chemicals (industries 23-24) and in electrical and electronic machinery and equipment (industries 30-33). Danish firms are more R\&Dintensive than Irish firms. Only in wood, paper and printing is Ireland ahead 
of Denmark. However, Irish firms declare a higher percentage of sales in new or improved products than Danish firms in 6 out of the 11 industries.

In table 4 we examine the pairwise correlations between the four quantitative innovation measures. The two input indicators and the two output indicators are highly correlated, which is normal since one is a component of the other one. Moreover there is probably a time lag between the inputs and the outputs of innovation which, given the cross-sectional nature of our data, we are unable to take into account.

The main conclusions we can draw from the analysis of the partial indicators of the Danish and Irish CIS 1 data can be summarized as follows:

1. Current expenditures on innovation is a variable of dubious quality.

2. There is more to innovation expenditures than $R \& D$ but the two measures are highly correlated. The correlations are around 0.65 at the firm level.

3. There is more correlation between $R \& D$ and current expenditures on innovation or between sales of new products and sales of products new to the industry than there is between any of the two input and any of the two output indicators of innovation.

4. Each country has its own pattern of sectoral specialization in innova- 
tions.

In view of this, it might be advisable to consider a range of innovation indicators. It is, for instance, useful to look at both the input and the output indicators because they reveal different types of information. The input indicators are predictors of future innovations whereas the output indicators reflect past innovation efforts. One is forward-looking and the other one is backward-looking. The output indicators have the advantage over the input indicators to measure the success of innovation, that is, indirectly to give more weight to innovation efforts that turn out to be successful. Alternatively, one could consider devising a global innovation indicator taking these various dimensions of innovation into account and aggregrating them somehow in one index. This is the approach we shall pursue now.

\section{A composite innovation indicator}

A weighted index of the various measures could be constructed if a priori one was ready to put more weight on some pieces of information than on others. For instance, an innovation would be worth more if it corresponds to a product new to the industry than if it is merely new to the firm but 
not to the industry; or an incremental innovation would be worth less than a drastic innovation. Of course, these weights are subjective.

A more objective way of aggregating the various partial indicators is to perform a principal component analysis on them to extract combinations of variables which best summarize the total variation in the indexes. ${ }^{9}$ A global index of innovation intensity can then be obtained by taking the first principal component or the sum of the first two or three principal components. The ranking of firms by the principal components could be compared to the ranking according to individual responses. The drawback of this analysis is the absence of a model. In a way, one lets the data speak. It is therefore difficult to interpret the resulting principal components or the resulting global innovation index. Usually the principal components are named after the variables with the highest factor loadings. By using a varimax rotation, i.e. a transformation of the factor loadings, in order to produce a simple loading structure, one can venture to give a more clear-cut interpretation

\footnotetext{
${ }^{9}$ Alternatively, one could do a factor analysis. In a principal component analysis, the aim is to account for the maximum of the variance and covariance among the original variables (in this case the innovation indicators). In a factor analysis, the goal is only to explain as much as possible the interconnection between the variables (see Reyment and Jöreskog (1993)).
} 
to each factor. Moreover, all information is treated as equally important, whereas we know a priori that some variables are better measured or more informative than others. For instance, Crépon, Duguet and Kabla (1996) find unbelievable results using the dichotomous variable of innovation, which are incompatible with the results obtained using the variable "shares of sales from new products". They suspect a large measurement error in the former variable, suspecting small firms to be more inclined to report innovations which larger ones would not regard as such.

Hollenstein (1996) has performed such a factor analysis on Swiss innovation survey data. The technical dimension of the data $(\mathrm{R} \& \mathrm{D}$ and technical assessment of innovation) and the market orientation (share in sales of new products) are the two factors singled out for product innovation, and the input and the output side of the innovation process $(R \& D$ and technological and economic assessment of innovation) are the two factors identifying process innovations. Hollenstein (1996) relates his factor-based innovation measures to explanatory variables of innovation by way of a canonical correlation analysis. He finds that the composite indicator is more correlated to the set of explanatory variables (demand expectation, market structure, knowledge appropriability, technological opportunities) than any partial indicator. A 
potential drawback of his analysis is that he examines only innovating firms.

Baldwin and Johnson (1996) define innovative firms as those above the median value in the ranking on the first principal component from 19 variables pertaining to innovations (table 1, p. 791). From the "Growing Small and Medium-Sized Enterprise Survey", conducted in 1989 on Canadian firms, they use the responses of 820 firms to questions relating to the activities of the firms (e.g. export performance, sources of financing, training, marketing, intensity of R\&D), to their characteristics profile (region of operation, ownership structure, country of control, size, occupational distribution, involvment in mergers and acquisitions), and to their strategies (regarding marketing, inputs, technology acquisition, management techniques, humanresource). They find that innovative firms differ from non-innovative firms in many respects (using the non-parametric Wilcoxon rank sum test): they value human resources more highly, they place greater emphasis on the importance of marketing, they strive for efficiency, they rely more on outside sources of financing, such as venture capital, public equity, and parents and affiliates, and less heavily on suppliers and financial institutions, they value general government programs, they view management skills as a key to success. While the authors distinguish innovating from non-innovating firms, 
they fall short of providing an index of innovativeness.

The other way of constructing a composite innovation indicator is the econometric prediction of the conditional expectation of innovation from an estimated explanatory model. Porter and Stern (1999) have constructed such an innovation capacity index. They estimate a national innovation capacity equation for 17 OECD countries and the period from 1973 to 1993 by regressing international patenting per head on a number of variables supposed to capture the basic determinants of innovation: factor conditions (human resources, basic research infrastructure, information infrastructure and the supply of risk capital), supporting environment (competition, innovation incentives, presence of clusters and local suppliers), and demand conditions (sophisticated customers, anticipated needs). Not all these variables are available for all countries or even easily measurable. Yet, on the basis of a certain number of explanatory variables, they estimate an index, which in their own words "is the expected number of international patents per million persons given a country's current configuration of national policies and resource commitments". This index can then be applied to other countries or future data to project their innovation capacities.

We shall in spirit follow their direction, but we shall depart from their 
work in three respects. First, we shall estimate a somewhat more structured model, taking into account the qualitative nature of some of the data available in the CIS surveys. Second, we shall base the index directly on firm data. Third, we shall extract information from both innovators and non-innovators.

\section{Model}

The main objective of this paper is to construct a composite indicator of innovation from the variables contained in the Community Innovation Surveys. The survey first identifies innovators and non-innovators. After giving some general information about their enterprise, respondents have to answer yes or no to the question "have you introduced a new product or a new process, or do you plan to do so in the near future?". If the answer is yes, then they are asked to give some figures about the amount of innovation input and output.

As was already mentioned above, quantitative data on innovation ( $R \& D$ expenditures, sales of new products) are available in CIS 1 only for those firms which introduced a new product or a new process between 1990 and 1992. Hence exploiting only those data would restrict us to the universe of innovating firms. If we limited ourselves to qualitative data, we could com- 
pute an ability to innovate index for all firms, but we would fail to exploit the information we have on the amount of their innovation. Therefore we suggest to estimate a generalized tobit model, with a separate structure for the probability of innovating and for the amount of innovation. The estimated model can be used to predict the probability of innovating and the amount of innovation, given a set of values for the conditional variables. Our index of innovation will then be defined as the conditional expectation of innovation, which can be evaluated at different levels of the conditioning variables. This procedure has the advantage of exploiting the dichotomous information available for all firms in the survey (not just the innovating ones) and the continuous variation contained in the quantitative data. Of course, only variables for which observations exist for all firms can enter the latent variable function. Given that certain variables are measured only for innovative firms, the difference in specification between the qualitative and the quantitative part of the generalized tobit is in part determined by the way the CIS 1 questionnaire was set up.

We thus model the determinants of innovation with two equations. The first one explains what makes a firm innovative or not. The second one determines the amount of innovation conditional on the fact that the firm is 
innovative. Formally, we assume that there is a latent variable $y_{i 1}^{*}$ for firm $\mathrm{i}$ generated by the first equation

$$
y_{1 i}^{*}=x_{1 i} b_{1}+u_{1 i}
$$

where $x_{1 i}$ is a vector of explanatory variables, $b_{1}$ is a vector of coefficients to be estimated, and $u_{i 1}$ is an error term due to unaccounted for influences, such as the quality of the managers, organizational effectiveness, and the degree of intellectual property protection.. If $y_{1 i}^{*}$ is positive, the firm has enough incentive to innovate and the dichotomous variable takes the value of one (corresponding to "yes, I innovated"). We expect the incentive to innovate to be a function of technological opportunity conditions: it is more easy to innovate in certain fields than in others. Since by and large opportunity conditions are industry-specific, they can be approximated by industry dummies. Industry dummies could also capture the effects of industry-targeted innovation policies. We also expect the incentive to innovate to depend on size. The size effect could reflect access to finance or scale economies. We have classified firms into six size classes: with a number of employees less than or equal to 49 , between 50 and 99 , between 100 and 249 , between 250 and 499, between 500 and 999, and above 1000. Past growth can be a determining 
factor, as a predictor of future growth, as a demand-pull effect (see Brouwer and Kleinknecht, 1999), or as a signal of easy access to capital financing. The growth of sales between 1990 and 1992 is available in the dataset. Firms that are part of a group are expected to benefit from knowledge spillovers, internal access to finance, or synergies in marketing, distribution, and so on, and to be more innovative because of this.

The only other variable available in the dataset, with observations for both innovative and non-innovative firms, that we could could bring forward to explain the probability of innovating is the degree of perception of the obstacles to innovation. We have not included this variable among the regressors for two reasons. First, perceptions are subjective and we do not want to predict innovations on the basis of some subjective variable. Second, various authors have found that the obstacles to innovation are more perceived when firms actually try to innovate and face those obstacles than when they do not innovate and hence do not encounter them (Baldwin and Lin, 1999, Mohnen and Rosa, 2000). The sign effect of this variable can thus go either way and therefore it is a bad predictor of the readiness to innovate.

The amount of innovation is modeled by another latent variable $y_{2 i}^{*}$. If the firm is innovative, $y_{2 i}^{*}=y_{2 i}$, the latent variable is equal to the actual 
amount of innovation, otherwise the latent variable is equal to zero, or nonobservable. Since the percentage of innovative sales is bounded by 0 and 1 , the dependent variable in the second equation is specified in log-ratio form (for a discussion of tobit models with bounded dependent variables, see Cragg (1971)):

$$
z_{2 i}^{*}=\ln \left(y_{2 i}^{*} /\left(1-y_{2 i}^{*}\right)\right)=x_{2 i} b_{2}+u_{2 i}
$$

where $x_{2 i}$ is a vector of explanatory variables, $b_{2}$ is a vector of coefficients to be estimated and $u_{2 i}$ is a stochastic error term reflecting omitted variables and other sources of heterogeneity. When $y_{2 i}^{*}=0, u_{2 i}=-\infty$ and when $y_{2 i}^{*}=1, u_{2 i}=\infty$. The explanatory variables in $x_{2 i}$ are in principle the same as those in $x_{1 i}$. However, for innovating firms we have more information to explain the amount of innovation. We shall add in $x_{2 i}$, in addition to the variables already intoduced in $x_{1 i}$, various dimensions of $\mathrm{R} \& \mathrm{D}$ : the dichotomous variable "doing $R \& D$ on a continuous rather than occasional basis", the dichotomous variable indicating whether $\mathrm{R} \& \mathrm{D}$ is done in cooperation with partners or not, and the $\mathrm{R} \& \mathrm{D} /$ sales ratio. We have not included current expenditures on innovation as an innovation input, because, as documented in section 2, this variable is badly measured. For the same reasons why we have excluded the perceived obstacles to innovation, we have also excluded 
the perceived strength of appropriability conditions for product or for process innovations.

Since $y_{2 i}^{*}$ is only observed when $y_{1 i}^{*} \geq 0, u_{1 i}$ and $u_{2 i}$ are likely to be correlated. We assume their joint distribution to be a bivariate normal distribution

$$
u_{i} \sim N(0, \Sigma)
$$

where $u_{i}=\left[\begin{array}{ll}u_{1 i} & u_{2 i}\end{array}\right]^{\prime}, \Sigma=\left[\begin{array}{lll}\sigma_{1}^{2} & \rho \sigma_{1} \sigma_{2} \mid \rho \sigma_{1} \sigma_{2} & \sigma_{2}^{2}\end{array}\right]$ and 0 is a $2 \mathrm{x} 1$ vector of zeros.

The generalized tobit model is estimated by maximum likelihood. We maximize the likelihood of observing the $y_{1 i}$ and $y_{2 i}$ in our sample. Since the dependent variable of the equation for the percentage of innovative sales has been transformed, a Jacobian has to be added to the log likelihood function to correct for the transformation. The log- likelihood function is given by

$$
\begin{aligned}
\ln L= & \sum_{o} \ln \left[1-\Phi\left(x_{1 i} b_{1} / \sigma_{1}\right)\right]+\sum_{1} \ln \Phi\left(\frac{x_{1 i} b_{1}+\left[\rho \sigma_{1} / \sigma_{2}\right]\left[\ln \left(y_{2 i} /\left(1-y_{2 i}\right)\right)-x_{2 i} b_{2}\right.}{\sigma_{1} \sqrt{1-\rho^{2}}}\right) \\
& +\sum_{1} \ln \left(1 / \sigma_{2}\right)\left[y_{2 i}\left(1-y_{2 i}\right)\right]^{-1} \phi\left[\left(y_{2 i}-x_{2 i} b_{2}\right) / \sigma_{2}\right]
\end{aligned}
$$

where the index 0 under the summation sign refers to non-innovators and the index 1 refers to innovators, $\Phi$ is the standard normal distribution func- 
tion and $\phi$ the standard normal density function. Since only $b_{1} / \sigma_{1}$ is identifiable, we shall put $\sigma_{1}=1$. Initial estimates are obtained from Heckman's two-step estimation: first, estimate the probit equation and compute from it the inverse Mills ratio, and second, introduce this ratio as an additional regressor in the ordinary least squares regression of the second equation, run on positive values of $y_{1 i}$. Estimates of $\rho$ and $\sigma_{2}$ can be retrieved from these estimates (see Gouriéroux (1989), p.209). We assume the $\mathrm{u}_{i}$ error terms to be independently and identically distributed over all observations.

Our proposed index of innovation is then defined as the expected percentage of innovative sales for each enterprise conditional upon the values taken by the explanatory variables. The mean of $y_{2 i}$ conditional on the observed values for the explanatory variables $x_{1 i}$ and $x_{2 i}$ is equal to

$$
E\left(y_{2 i} \mid x_{1 i}, x_{2 i}\right)=\int_{-x_{1 i} b_{1}}^{\infty} \int_{0}^{1} y_{2 i} f\left(u_{1 i}, y_{2 i}\right) d u_{1 i} d y_{2 i}
$$

After some manipulations, this expression can be shown to be retrieved from the area under a bivariate standard normal distribution function by the following formula

$E\left(y_{2 i} \mid x_{1 i}, x_{2 i}\right)=\int_{-x_{1 i} b_{1}}^{\infty} \int_{-\infty}^{\infty} \exp \left(x_{2 i} b_{2}+\sigma_{2} u_{2 i}^{*}\right) /\left(1+\exp \left(x_{2 i} b_{2}+\sigma_{2} u_{2 i}^{*}\right)\right) f\left(u_{1 i}^{*}, u_{2 i}^{*}\right) d u_{1 i}^{*} d u_{2 i}^{*}$

where $u_{2 i}^{*}=u_{2 i} / \sigma_{2}, u_{1 i}^{*}=u_{1 i}$ and $f\left(u_{2 i}^{*}, u_{1 i}^{*}\right)$ is the bivariate standard 
normal distribution with correlation coefficient $\rho$. This conditional mean is then evaluated at the estimated values of $b_{1}, b_{2}, \rho$ and $\sigma_{2} \cdot{ }^{10}$

\section{Results}

As a measure of the amount of innovation $y_{2 i}$, we take the share in sales of new, incrementally improved or significantly improved products, as no data are available in Ireland for the alternative sharper measure of innovation, the share in sales of products new to the industry. Some enterprises declare to have introduced a new product or process but report no share in sales due to new products. There could be a time lag between the introduction of a new product on the market and the realisation of sales from this new product. As we cannot account for any time lags, we attribute the value of 0 or 1 to $y_{1 i}$

\footnotetext{
${ }^{10}$ Kleinknecht and Kleinknecht (1996) have estimated a similar model on the Dutch CIS I data. They compared the determinants of the probability and of the intensity of innovation using three types of indicators: the sales share of innovative products, the sales share of imitative products and the number of new product and service announcements in journals. They estimated this model on manufacturing as well as on service data and they had access to original enterprise data instead of micro-aggregated data. They did not, however, use their estimates to predict innovation and compare it across countries.
} 
according to whether $y_{2 i}$ is equal to zero or takes a positive value. Missing data for $y_{2 i}$ are treated as zero responses. Missing data for $\mathrm{R} \& \mathrm{D}$ are also considered as zero responses.

Table 5 presents some descriptive statistics. There are $62 \%$ of innovating firms in the Danish sample and $68 \%$ in the Irish sample. The unweighted average of the share in sales of innovative products is $26.6 \%$ in Denmark and $29.0 \%$ in Ireland. In table 3 we reported economy-wide or sales-weighted average of $35.5 \%$ and $31.5 \%$ respectively. The Danish sample has somewhat bigger firms than the Irish sample. Indeed, when we look at the size distribution by the number of employees we notice that the mode of the distribution is in the 100-249 category in Denmark and in the 50-99 category in Ireland. As large firms innovate more often than small firms (as we shall see), it is normal that the weighted averages are larger than the unweighted averages. A larger percentage of the Danish firms belong to a group. The mean R\&D intensity is similar in both countries, the variance is somewhat greater in Denmark. Whereas more of the Danish firms cooperate on R\&D, less of them, compared to the Irish, do R\&D on a continuous basis.

Tables 6 and 7 present the maximum likelihood estimates of the generalized tobit model for Denmark and Ireland respectively. The reference group 
is the smallest size class (betwen 20 and 50 employees) of enterprises in the food, beverage and tobacco sector, with independent status, who do not engage in collaborative and continuous $R \& D$. The continuous variables (number of employees, $\mathrm{R} \& \mathrm{D} /$ sales and sales growth rate) have been normalized. In Denmark, the propensity to innovate is high in the sectors chemicals, machinery and equipment, and electrical products, but also in vehicles. Innovative sales are high in those same sectors plus textiles. In Ireland, the innovative sectors, both in the percentage of innovative firms and in the sales share in innovative products, are textiles, machinery and equipment, and electrical products. Firms of greater size have a higher probability to innovate, but the relationship between size and the probability of innovating is nonlinear. In both countries, the share in sales of innovative products is not stongly related to firm size.

Danish firms which belong to a larger consortium have a significantly higher probability to innovate and also a higher share in sales of innovative products. In Ireland, this variable hardly matters. Exactly the opposite holds for past growth in sales. It has no effect on innovation in Denmark, whereas in Ireland it significantly increases both dimensions of innovation. Regarding $R \& D$, the input into the innovation process, only the property of being a 
continuous R\&D performer exerts a significantly positive effect on the share in sales of innovative products in both countries. In Ireland, the R\&D/sales coefficient is marginally significant. In both countries, collaborative R\&D does not in itself increase innovative sales. The correlation coefficient $\rho$ between the error terms $\mathrm{u}_{1 i}$ and $\mathrm{u}_{2 i}$ is high but imprecisely estimated in both countries.

From these estimates of the qualitative and quantitative information of innovation contained in the CIS 1 data, we can compute for each observation in the sample the mean expected share in sales of innovative products conditional on the observed values of the explanatory variables. This expectation is computed from the joint probability distribution of the error terms in both equations, the estimated threshold above which an enterprise becomes innovative, and the estimated regression line of the share of innovative sales. In table 8 we report the weighted averages by industry of the expected conditional shares of innovative sales and of the observed shares of innovative sales, over all enterprises (innovative or not). The difference between the two averages is due to the fact that in the former we use the probability of innovating, which lies between zero and one, and the predicted amount of innovation conditional on being above the innovative threshold, and in the 
latter we use the actual amount of innovative sales for innovators and zero for non-innovators.

In Denmark, the expected conditional average share in sales of innovative products for all firms is $35.2 \%$, not too far away from the observed average of $35.6 \%$. In Ireland the two figures are even closer, $31.1 \%$ versus $31.5 \%$. The correlation between the observed and predicted innovation performances weighted by the respective sales is 0.84 for all firms in Denmark and 0.64 in Ireland. It means that in eight out of ten cases (six out of ten resp.) when the actual figure is high (above its mean) the expected is high as well, or both of them are low. The correlations are even higher for actual innovators. The conditional expectations are substantially below the actual performance for innovators: $35.6 \%$ against $47.6 \%$ for Denmark and $31.6 \%$ versus $41.0 \%$ for Ireland. However, for actual non-innovators we predict a substantially higher share in sales of innovative products: $22.8 \%$ in Denmark and $24.4 \%$ in Ireland. At the industry level, the correlations between the expected conditional shares and the actual shares are most of the time above 0.5 and often even above 0.7 . The industrial rankings in terms of expected percentages of innovative sales are different from the rankings on the basis of the observed percentages. The top innovative sectors are machinery and equipment and 
vehicles, followed by electrical products, chemicals and textile in Denmark, and machinery and equipment, electrical products and textile in Ireland. In both countries the food industry is much more innovative than actual figures make it look like whereas the opposite holds for the wood industry in Denmark and the chemicals industry in Ireland. The greatest difference between our measure and the actual statistics on the percentages of innovative sales regards the non-innovators. Even non-innovators have a capacity to innovate given the innovation determinants we have taken into account. But their expected innovation record is lower than for actual innovators.

If we want to compare Denmark and Ireland, we must have a common structure. The figures in table 9 are not comparable because they are derived from two sets of estimates. One solution would be to estimate a common structure for the data generation process, the other solution would be to compare their respective performance taking one of the two estimated structures. The latter is what table 9 reports. In the first two columns we compute the expected conditional means using the estimated Danish model, in the last two columns we use the estimated Irish model. By analysing table 9, we can draw four conclusions. First, the conditional predictions obtained with both estimates are pretty close. Second, except for one industry the bilateral rank- 
ings between the two countries in terms of their expected shares of innovative sales are identical. Third, Denmark seems slightly more innovative than Ireland, except perhaps for those firms that did not innovate between 1990 and 1992. Fourth, if we disregard the textile sector where the two estimates do not pick the same winner, our results find Denmark more innovative than Ireland in the production of petroleum and chemical products, rubber and plastic, basic and fabricated metals, machinery and equipment and motor vehicles and transportation equipment.

\section{Conclusion}

The Community Innovation Survey data contain a lot of information to construct an innovation index, innovation being more encompassing than R\&D. It contains quantitative, dichotomous and polychotomous variables, and information about the input, the output, and the modalities of innovation. We suggest to construct a composite indicator of innovation taking many of these variables into account. Innovation is measured as the expected mean share of sales due to new or improved products conditional on the innovation input, the way innovation is organized, and some characteristics of the firm 
and its environment. The indicator is based on a generalized tobit model which models the propensity to innovate and the amount of innovation in case of innovation. It combines the quantitative and qualitative variables contained in the database. The former are richer in content than zero/one or categorical variables, as they are measurable on a continuous rather than on just a discrete basis. However, they only pertain to innovating firms. They are supplemented by constructing aptitudes of innovation for all firms transforming a dichotomous variable into a continuous one.

An exploratory application of this measure to Danish and Irish innovation data from CIS 1 shows that it can be applied, even within the limited set of data available in CIS 1. It allows comparison between countries, industries, firms in different size classes, innovators and non-innovators. By providing an explanation for the propensity to innovate and the intensity of innovation, it indirectly explains what makes a firm innovative. Counterfactual experiments can then be run applying the characteristics of one firm to another firm to compare innovation performances.

Our analysis leads us to conclude that the CIS 1 data indicate that Denmark is slightly more innovative than Ireland, but not to a great extent. The potential to innovate for actual non-innovators is pretty much the same in 
both countries.

The indicator could be further improved in several directions. First, if data on sales of products new to the industry were available for both countries, we could in a similar vein construct a sort of true innovation indicator, while the above analysis was confined to imitators (products new to the firm but not to the industry). Second, if data from CIS surveys could be merged with other kind of data for the same respondent, such as capital, patent, or balance sheet data, we would have a good chance to improve the predictive performance of our model and construct more reliable innovation indicators. Third, the innovation indicators may not to be representative for the entire population of firms in the various subsamples. We could blow up the data to the entire population, since the CIS survey provides raising factors. However, these factors should be specific to each variable. Grossing up all variables by a common factor would not change the innovation ratios. Fourth, we could also estimate a common innovation structure by estimating the model on pooled data. Fifth, we could generalize the model along the lines of Crépon, Duguet and Mairesse (1998) by allowing for simultaneity between R\&D, innovations and exports. 


\title{
7 References
}

\author{
Albach, H., D.B. Audretsch, M. Fleischer, R. Greb, E. Höfs, L.-H. \\ Röller, I. Schulz (1996), "Innovation in the European Chemical Industry", \\ WZB IV 96-26.
}

Archibugi, D., P. Cohendet, A. Kristensen, and K.-A. Schäffer (1994), Evaluation of the Community Innovation Survey (CIS), Phase I, EIMS publication no. 11, IKE Group, Department of Business Studies, Aalborg, Denmark.

Auzeby, F. (1994), "Des innovations de produits plutôt que de procédés", in Les Chiffres Clés. L'Innovation Technologique dans l'Industrie. Ministère de l'Industrie, des Postes et Télécommunications et du Commerce Extérieur, Dunod, Paris.

Baldwin, J.R. and G. Gellatly (2000), "A Firm-Based Approach to Industry Classification: Identifying the Knowledge-Based Economy", in Doing Business in a Knowledge-Based Economy. Facts and Policy Challenges, L.A. Lefebvre, E. Lefebvre and P. Mohnen (eds.), Kluwer Academic Publishers, Boston (forthcoming).

Baldwin, J. R. and J. Johnson (1996), "Business Strategies in More-and Less-Innovative Firms in Canada", Research Policy, 25, 785-804. 
Baldwin, J. and Z. Lin (1999), "Impediments to Advanced Technology Adoption for Canadian Manufacturers", mimeo.

Brouwer, E. and A. Kleinknecht (1996), "Determinants of Innovation: A Micro Econometric Analysis of Three Alternative Innovative Output Indicators", in Determinants of Innovation, the Message from new Indicators, A.H. Kleinknecht (ed.), Macmillan Press, London, 99-124.

Brouwer, E. and A. Kleinknecht (1997), "Measuring the Unmeasurable: A Country's Non-R\&D Expenditure on Product and Service Innovation", Research Policy, 25, 1235-1242.

Brouwer, E. and A. Kleinknecht (1999), "Keynes-plus? Effective demand and changes in firm-level R\&D: an empirical note", Cambridge Journal of Economics, 23, 385-391.

Cragg, J. (1971), "Some Statistical Models for Limited Dependent Variables With Application to the Demand for Durable Goods", Econometrica, 39, 829-844.

Crépon, B., E. Duguet and I. Kabla (1996), "Schumpeterian Conjectures: A Moderate Support from Various Innovation Measures", in Determinants of Innovation. The Message from New Indicators, A. Kleinknecht (ed.). Macmillan Press, London. 
Crépon, B., E. Duguet and J. Mairesse (1998), "Research and Development, Innovation and Productivity: An Econometric Analysis at the Firm Level", Economics of Innovation and New Technology, 7(2), 115-158.

Eurostat (1996), Manual on Disclosure Control Methods. 9E, Statistical Office of the European Communities, Luxembourg.

Felder, J., G. Licht, E. Nerlinger and H. Stahl (1995), "Appropriability, Opportunity, Firm Size and Innovation Activities. Empirical Results Using East and West German Firm Level Data", ZEW Discussion paper No. 95-21.

Gourieroux, C. (1989), Économétrie des Variables Qualitatives. Economica, Paris.

Hollenstein, H. (1996), "A Composite Indicator of a Firm's Innovativeness. An Empirical Analysis Based on Survey Data for Swiss Manufacturing", Research Policy, 25, 633-645.

Johnston, J. (1972), Econometric Methods (2nd ed.). McGraw-Hill, New York.

Kleinknecht, A.H. (1993), "Testing Innovation Indicators for Postal Surveys: results from a Five-Country Comparison", in A.H. Kleinknecht, D. Bain (eds.), New Concepts in Innovation Output Measurement, Macmillan, 
London, 153-188.

Kleinknecht, A. (1999), "Indicators of manufacturing and service innovation: Their strengths and weaknesses", in Metcalfe (ed.), forthcoming.

Maddala, G.S. (1983), Limited-Dependent and Qualitative Variables in Econometrics. Econometric Society Monographs in Quantitative Economics, Cambridge University Press, Cambridge.

Mohnen, P. and J. Rosa (2000), "Les obstacles à l'innovation dans les industries de service au Canada", Actualité Économique, forthcoming. Organization for Economic Co-operation and Development (1992,1996), Oslo Manual, Paris, 1st, 2nd edition.

Porter, M. and S. Stern (1999), The New Challenge to America's Prosperity: Findings from an Innovation Index. Council on Competitiveness, Washington, D.C.

Reyment, R. and K.G. Jöreskog (1993), Applied Factor Analysis in the Natural Sciences. Cambridge University Press, Cambridge.

Volle, M. (1985), Analyse des données (3rd ed.). Economica, Collection ENSAE, Paris. 
Table 1

Data selection: criteria and outcome

CIS I micro-aggregated data, 1992

\begin{tabular}{|c|c|c|}
\hline Criteria & Denmark & Ireland \\
\hline Original number of observ. & 674 & 999 \\
\hline Minus small enterprises & 644 & 762 \\
\hline $\begin{array}{c}\text { Minus missing industry } \\
\text { affiliation }\end{array}$ & 638 & 762 \\
\hline $\begin{array}{c}\text { Minus very high and small } \\
\text { growth rates }\end{array}$ & 578 & 692 \\
\hline $\begin{array}{c}\text { Minus too high and small } \\
\text { R\&D/sales and innov/sales }\end{array}$ & 559 & 692 \\
\hline
\end{tabular}


Table 2

Partial innovation indicators: count measures

Denmark and Ireland, CIS I, micro-aggregated data, 1992

\section{DENMARK}

\begin{tabular}{|c|c|c|c|c|c|}
\hline $\begin{array}{c}\text { Industry } \\
\text { NACE code }\end{array}$ & $\begin{array}{c}\text { Number of } \\
\text { firms }\end{array}$ & $\begin{array}{c}\text { Industry } \\
\text { distribution } \\
\text { of firms } \\
\text { (in \%) }\end{array}$ & $\begin{array}{c}\% \text { of } \\
\text { innovating } \\
\text { firms }\end{array}$ & $\begin{array}{c}\text { \% of firms } \\
\text { with } \\
\text { products } \\
\text { new to } \\
\text { industry }\end{array}$ & $\begin{array}{c}\text { \% of R\&D } \\
\text { performers }\end{array}$ \\
\hline FOOD & 72 & 12.9 & 50.0 & 30.6 & 43.0 \\
\hline TEXTILE & 24 & 4.3 & 50.0 & 25.0 & 33.3 \\
\hline WOOD & 69 & 12.3 & 44.9 & 15.9 & 20.3 \\
\hline CHEM. & 32 & 5.7 & 84.4 & 65.6 & 78.1 \\
\hline PLASTIC & 32 & 5.7 & 65.6 & 37.5 & 62.5 \\
\hline NON-MET & 28 & 5.0 & 67.9 & 50.0 & 57.1 \\
\hline METALS & 78 & 14.0 & 61.5 & 43.6 & 48.7 \\
\hline M\&E & 97 & 17.4 & 72.2 & 55.7 & 64.9 \\
\hline ELECTRIC & 64 & 11.4 & 82.8 & 67.2 & 78.1 \\
\hline VEHIC & 27 & 4.8 & 63.0 & 44.4 & 63.0 \\
\hline NEC & 36 & 6.4 & 38.9 & 25.0 & 25.0 \\
\hline Total & 559 & 100.0 & 62.3 & 42.8 & 52.1 \\
\hline
\end{tabular}

\section{IRELAND}

\begin{tabular}{|c|c|c|c|c|c|}
\hline $\begin{array}{c}\text { Industry } \\
\text { NACE code }\end{array}$ & $\begin{array}{c}\text { Number of } \\
\text { firms }\end{array}$ & $\begin{array}{c}\text { Industry } \\
\text { distribution } \\
\text { of firms } \\
\text { (in \%) }\end{array}$ & $\begin{array}{c}\text { \% of } \\
\text { innovating } \\
\text { firms }\end{array}$ & $\begin{array}{c}\text { \% of firms } \\
\text { with } \\
\text { products } \\
\text { new to } \\
\text { industry }\end{array}$ & $\begin{array}{c}\text { \% of R\&D } \\
\text { performers }\end{array}$ \\
\hline FOOD & 101 & 14.6 & 63.4 & - & 59.4 \\
\hline TEXTILE & 68 & 9.8 & 76.5 & - & 64.7 \\
\hline WOOD & 84 & 12.1 & 45.2 & - & 41.7 \\
\hline CHEM. & 80 & 11.6 & 73.8 & - & 68.7 \\
\hline PLASTIC & 52 & 7.5 & 71.2 & - & 57.7 \\
\hline NON-MET & 31 & 4.5 & 64.5 & - & 61.3 \\
\hline METALS & 69 & 10.0 & 62.3 & - & 56.5 \\
\hline M\&E & 50 & 7.2 & 70.0 & - & 62.0 \\
\hline ELECTRIC & 108 & 15.6 & 83.3 & - & 74.1 \\
\hline VEHIC & 16 & 2.3 & 62.5 & - & 43.7 \\
\hline NEC & 33 & 4.8 & 69.7 & - & 60.6 \\
\hline Total & 692 & 100.0 & 68.1 & - & 60.7 \\
\hline
\end{tabular}


Table 3

Partial innovation indicators: quantitative measures (in percentages)

Denmark and Ireland, CIS I, micro-aggregated data, 1992

DENMARK

\begin{tabular}{|c|c|c|c|c|c|c|c|c|}
\hline \multirow[t]{2}{*}{$\begin{array}{c}\text { Industry } \\
\text { NACE code }\end{array}$} & \multicolumn{2}{|c|}{$\begin{array}{l}\text { Expenditures of } \\
\text { R\&D/total sales }\end{array}$} & \multicolumn{2}{|c|}{$\begin{array}{c}\text { Current } \\
\text { Innovation } \\
\text { expenditures } \\
\text { /total sales }\end{array}$} & \multicolumn{2}{|c|}{$\begin{array}{l}\text { Sales of new } \\
\text { products/total } \\
\text { sales }\end{array}$} & \multicolumn{2}{|c|}{$\begin{array}{c}\text { Sales of } \\
\text { products new to } \\
\text { industry/total } \\
\text { sales }\end{array}$} \\
\hline & $\begin{array}{c}\text { All } \\
\text { firms }\end{array}$ & $\begin{array}{c}\text { innova } \\
\text { tors }\end{array}$ & $\begin{array}{c}\text { All } \\
\text { firms }\end{array}$ & $\begin{array}{c}\text { Innova } \\
\text { tors }\end{array}$ & $\begin{array}{c}\text { All } \\
\text { firms }\end{array}$ & $\begin{array}{c}\text { Innova } \\
\text { tors }\end{array}$ & $\begin{array}{c}\text { All } \\
\text { firms }\end{array}$ & $\begin{array}{c}\text { innova } \\
\text { tors }\end{array}$ \\
\hline FOOD & 1.3 & 2.5 & 0.5 & 0.9 & 12.1 & 22.6 & 4.4 & 8.1 \\
\hline TEXTILE & 1.0 & 1.9 & 1.2 & 2.3 & 41.8 & 79.2 & 18.2 & 34.5 \\
\hline WOOD & 0.4 & 0.5 & 1.2 & 1.6 & 26.2 & 35.9 & 3.8 & 5.2 \\
\hline CHEM. & 7.4 & 8.8 & 4.5 & 5.4 & 43.9 & 53.3 & 19.2 & 23.3 \\
\hline PLASTIC & 2.0 & 2.8 & 2.8 & 3.8 & 21.5 & 29.9 & 3.2 & 4.5 \\
\hline NON-MET & 0.9 & 1.1 & 1.7 & 2.1 & 13.7 & 16.9 & 3.3 & 4.0 \\
\hline METALS & 2.4 & 3.2 & 1.9 & 2.6 & 26.3 & 35.8 & 3.7 & 5.0 \\
\hline M\&E & 5.9 & 6.5 & 2.7 & 3.0 & 60.2 & 66.7 & 14.9 & 16.5 \\
\hline ELECTRIC & 7.8 & 8.4 & 7.5 & 8.0 & 45.0 & 48.1 & 18.1 & 19.4 \\
\hline VEHIC & 3.5 & 3.7 & 3.8 & 4.0 & 80.3 & 84.0 & 46.5 & 48.7 \\
\hline NEC & 1.2 & 2.1 & 1.4 & 2.6 & 25.9 & 47.1 & 5.1 & 9.4 \\
\hline Total & 3.5 & 4.7 & 2.5 & 3.3 & 35.5 & 47.6 & 12.7 & 16.9 \\
\hline Small firms* & 2.0 & 3.2 & 2.4 & 4.0 & 24.5 & 39.7 & 6.8 & 11.1 \\
\hline \multicolumn{9}{|c|}{ IRELAND } \\
\hline $\begin{array}{l}\text { Industry } \\
\text { NACE code }\end{array}$ & \multicolumn{2}{|c|}{$\begin{array}{l}\text { Expenditures of } \\
\text { R\&D/total sales }\end{array}$} & \multicolumn{2}{|c|}{$\begin{array}{c}\text { Current } \\
\text { Innovation } \\
\text { expenditures } \\
\text { /total sales }\end{array}$} & \multicolumn{2}{|c|}{$\begin{array}{l}\text { Sales of new } \\
\text { products/total } \\
\text { sales }\end{array}$} & \multicolumn{2}{|c|}{$\begin{array}{c}\text { Sales of } \\
\text { products new to } \\
\text { industry/total } \\
\text { sales }\end{array}$} \\
\hline & $\begin{array}{c}\text { All } \\
\text { firms }\end{array}$ & $\begin{array}{c}\text { Innova } \\
\text { tors }\end{array}$ & $\begin{array}{c}\text { All } \\
\text { firms }\end{array}$ & $\begin{array}{c}\text { Innova } \\
\text { tors }\end{array}$ & $\begin{array}{c}\text { All } \\
\text { firms }\end{array}$ & $\begin{array}{c}\text { Innova } \\
\text { tors }\end{array}$ & $\begin{array}{c}\text { All } \\
\text { firms }\end{array}$ & $\begin{array}{c}\text { Innova } \\
\text { tors }\end{array}$ \\
\hline FOOD & 0.7 & 1.0 & 0.6 & 0.8 & 21.1 & 32.1 & - & - \\
\hline TEXTILE & 1.1 & 1.3 & 1.6 & 2.0 & 30.3 & 37.3 & - & - \\
\hline WOOD & 1.2 & 1.6 & 2.5 & 2.7 & 21.8 & 35.1 & - & - \\
\hline CHEM. & 2.5 & 3.1 & 3.7 & 4.6 & 27.8 & 36.0 & - & - \\
\hline PLASTIC & 1.3 & 1.5 & 2.7 & 3.1 & 44.7 & 51.2 & - & - \\
\hline NON-MET & 0.4 & 0.4 & 1.2 & 1.2 & 37.5 & 38.1 & - & - \\
\hline METALS & 1.4 & 2.6 & 2.3 & 3.2 & 31.2 & 51.1 & - & - \\
\hline $\mathrm{M} \& \mathrm{E}$ & 0.8 & 0.9 & 3.5 & 3.8 & 64.5 & 74.0 & - & - \\
\hline ELECTRIC & 2.3 & 2.6 & 5.5 & 6.1 & 49.6 & 55.4 & - & - \\
\hline VEHIC & 1.2 & 1.4 & 2.5 & 3.1 & 21.1 & 28.4 & - & - \\
\hline NEC & 0.7 & 0.9 & 2.0 & 2.6 & 24.4 & 33.6 & - & - \\
\hline Total & 1.3 & 1.6 & 2.2 & 2.8 & 31.5 & 41.0 & - & - \\
\hline Small firms* & 2.2 & 3.0 & 3.9 & 5.3 & 29.4 & 39.2 & -- & - \\
\hline
\end{tabular}

*Small firms are defined as those with below medium sales 
Table 4

Correlations between partial innovation indicators for innovating firms Denmark and Ireland, CIS I, micro-aggregated data, 1992

\begin{tabular}{|c|c|c|c|c|c|c|}
\hline & \multicolumn{2}{|c|}{$\begin{array}{c}\text { Current innovation } \\
\text { expenditures/total } \\
\text { sales }\end{array}$} & \multicolumn{2}{|c|}{$\begin{array}{c}\text { Sales of new } \\
\text { products/total sales }\end{array}$} & \multicolumn{2}{|c|}{$\begin{array}{c}\text { Sales of products new } \\
\text { to industry /total sales }\end{array}$} \\
\hline & Denmark & Ireland & Denmark & Ireland & Denmark & Ireland \\
\hline $\begin{array}{c}\text { R\&D/total } \\
\text { sales }\end{array}$ & 0.63 & 0.68 & 0.06 & 0.09 & 0.08 & - \\
\hline $\begin{array}{c}\text { Current } \\
\text { innovation } \\
\text { expendit. } \\
\text { /total sales }\end{array}$ & & & 0.08 & 0.01 & 0.09 & - \\
\hline $\begin{array}{c}\text { Sales of } \\
\text { new } \\
\text { products } \\
\text { /total sales }\end{array}$ & & & & & 0.47 & - \\
\hline
\end{tabular}


Table 5

Summary statistics: Denmark and Ireland

CIS I, micro-aggregated data, 1992

(sample mean with sample standard deviation in parenthesis for continuous variables)

\begin{tabular}{|c|c|c|}
\hline Variable & Denmark & Ireland \\
\hline Dummy for innovators & 0.623 & 0.681 \\
\hline \% in sales of innovative products & 0.266 & 0.290 \\
& $(0.294)$ & $(0.308)$ \\
\hline Dummy for 50-99 employees & 0.242 & 0.249 \\
\hline Dummy for 100-249 employees & 0.304 & 0.194 \\
\hline Dummy for 250-499 employees & 0.141 & 0.090 \\
\hline Dummy for 500-999 employees & 0.047 & 0.028 \\
\hline Dummy for >999 employees & 0.032 & 0.007 \\
\hline Dummy for being part of a group & 0.658 & 0.606 \\
\hline Sales growth (1990-92) & 0.082 & 0.162 \\
\hline R\&D/sales & $(0.230)$ & $(0.235)$ \\
\hline R\&D & 0.023 & 0.020 \\
& $(0.048)$ & $(0.036)$ \\
\hline Dummy for doing cooperative & 0.340 & 0.464 \\
\hline continuously & 0.379 & 0.262 \\
\hline
\end{tabular}


Table 6. Maximum likelihood estimates of a generalized tobit model of innovative sales Denmark, CIS I, micro-aggregated data, 1992

\begin{tabular}{|c|c|c|c|c|}
\hline Variables & $\begin{array}{l}\text { Propensity to } \\
\text { innovate }\end{array}$ & $\begin{array}{l}\text { Asymptotic } \\
\text { t-value }\end{array}$ & $\begin{array}{l}\text { Intensity of } \\
\text { innovation }\end{array}$ & $\begin{array}{l}\text { Asymptotic t- } \\
\text { value }\end{array}$ \\
\hline Constant & -0.631 & -3.28 & -2.550 & -6.92 \\
\hline TEXTILE & 0.395 & 1.32 & 1.751 & 3.18 \\
\hline WOOD & 0.098 & 0.44 & -0.192 & -0.46 \\
\hline CHEM. & 0.848 & 2.85 & 0.882 & 1.82 \\
\hline PLASTIC & 0.314 & 1.15 & 0.242 & 0.51 \\
\hline NON-MET & 0.495 & 1.71 & -0.522 & -1.04 \\
\hline METALS & 0.365 & 1.63 & -0.041 & -0.10 \\
\hline $\mathrm{M} \& \mathrm{E}$ & 0.763 & 3.64 & 1.169 & 3.20 \\
\hline ELECTRIC & 0.865 & 3.60 & 1.307 & 3.19 \\
\hline VEHIC & 0.805 & 2.73 & 1.378 & 2.73 \\
\hline $\mathrm{NEC}$ & -0.041 & -0.14 & 0.463 & 0.85 \\
\hline 50-99 employees & 1.311 & 1.10 & - & - \\
\hline 100-249 employees & 0.219 & 1.75 & - & - \\
\hline 250-499 employees & 0.564 & 3.25 & - & - \\
\hline 500-999 employees & 0.350 & 1.41 & - & - \\
\hline > 999 employees & 1.431 & 3.01 & - & - \\
\hline Number of employees & - & - & 0.076 & 0.98 \\
\hline Part of a group & 0.459 & 3.79 & 0.541 & 2.62 \\
\hline $\begin{array}{c}\text { Sales growth rate: } \\
1990-1992\end{array}$ & 0.027 & 0.47 & 0.010 & 0.11 \\
\hline R\&D/sales & - & - & 0.019 & 0.26 \\
\hline $\begin{array}{l}\text { Doing R\&D on a } \\
\text { continuous basis }\end{array}$ & - & - & 0.345 & 2.17 \\
\hline $\begin{array}{c}\text { Doing cooperative } \\
\text { R\&D }\end{array}$ & - & - & 0.209 & 1.31 \\
\hline $\begin{array}{l}\text { Estimated standard } \\
\text { error of error term }\end{array}$ & 1 (assumed) & - & 1.885 & 18.90 \\
\hline $\begin{array}{c}\text { Correlation coefficient } \\
\rho\end{array}$ & \multicolumn{2}{|c|}{-} & 0.921 & 1.24 \\
\hline
\end{tabular}


Table 7. Maximum likelihood estimates of generalized tobit Ireland, CIS I, micro-aggregated data, 1992

\begin{tabular}{|c|c|c|c|c|}
\hline Variables & $\begin{array}{l}\text { Propensity to } \\
\text { innovate }\end{array}$ & $\begin{array}{l}\text { Asymptotic } \\
\text { t-value }\end{array}$ & $\begin{array}{l}\text { Intensity of } \\
\text { innovation }\end{array}$ & $\begin{array}{c}\text { Asymptotic } \\
\text { t-value }\end{array}$ \\
\hline Constant & 0.540 & 0.41 & -2.343 & -7.78 \\
\hline TEXTILE & 0.560 & 2.92 & 1.438 & 3.75 \\
\hline WOOD & -0.357 & -2.02 & -0.165 & -0.42 \\
\hline CHEM. & 0.231 & 1.28 & 0.365 & 0.99 \\
\hline PLASTIC & 0.249 & 1.21 & 0.557 & 1.32 \\
\hline NON-MET & 0.206 & 0.86 & 0.031 & 0.07 \\
\hline METALS & 0.263 & 1.35 & 0.178 & 0.45 \\
\hline M\&E & 0.401 & 1.93 & 1.73 & 4.00 \\
\hline ELECTRIC & 0.513 & 2.94 & 1.176 & 3.42 \\
\hline VEHIC & 0.061 & 0.18 & 0.435 & 0.62 \\
\hline NEC & 0.449 & 1.84 & 0.664 & 1.34 \\
\hline 50-99 employees & 0.197 & 2.22 & - & - \\
\hline 100-249 employees & 0.039 & 0.40 & - & - \\
\hline 250-499 employees & 0.361 & 2.37 & - & - \\
\hline 500-999 employees & 1.189 & 4.05 & - & - \\
\hline > 999 employees & 0.441 & 0.79 & - & - \\
\hline Number of employees & - & - & 0.108 & 1.21 \\
\hline Part of a group & 0.132 & 1.20 & 0.018 & 0.08 \\
\hline $\begin{array}{c}\text { Sales growth rate: } \\
1990-1992\end{array}$ & 0.092 & 1.84 & 0.338 & 3.34 \\
\hline $\mathrm{R} \& \mathrm{D} / \mathrm{sales}$ & - & - & 0.107 & 1.64 \\
\hline $\begin{array}{l}\text { Doing R\&D on a } \\
\text { continuous basis }\end{array}$ & - & - & 0.340 & 2.17 \\
\hline $\begin{array}{c}\text { Doing cooperative } \\
\text { R\&D }\end{array}$ & - & - & 0.153 & 0.97 \\
\hline $\begin{array}{l}\text { Estimated standard } \\
\text { error of error term }\end{array}$ & \multicolumn{2}{|c|}{1 (assumed) } & 2.32 & 23.43 \\
\hline $\begin{array}{c}\text { Correlation coefficient } \\
\rho\end{array}$ & & & 0.96 & 1.28 \\
\hline
\end{tabular}


Table 8

Composite innovation indicator :

Denmark and Ireland, CIS I, micro-aggregated data, 1992

\begin{tabular}{|c|c|c|c|c|c|c|}
\hline & \multicolumn{3}{|c|}{ DENMARK } & \multicolumn{3}{|c|}{ IRELAND } \\
\hline & \multicolumn{6}{|c|}{ Share in sales of new products } \\
\hline Industry & $\begin{array}{l}\text { Predicted } \\
\text { conditional } \\
\text { mean } \\
\text { (weighted } \\
\text { average), } \\
\text { in \% }\end{array}$ & $\begin{array}{c}\text { Observed } \\
\text { weighted } \\
\text { average } \\
\text { in } \%\end{array}$ & $\begin{array}{c}\text { Correlation } \\
\text { between } \\
\text { observed } \\
\text { and } \\
\text { predicted }\end{array}$ & $\begin{array}{l}\text { Predicted } \\
\text { conditional } \\
\text { mean } \\
\text { (weighted } \\
\text { average), } \\
\text { in \% }\end{array}$ & $\begin{array}{c}\text { Observed } \\
\text { weighted } \\
\text { average } \\
\text { in } \%\end{array}$ & $\begin{array}{c}\text { Correlation } \\
\text { between } \\
\text { observed } \\
\text { and } \\
\text { predicted }\end{array}$ \\
\hline All firms & 32.3 & 35.5 & 0.84 & 31.1 & 31.4 & 0.64 \\
\hline innovators & 35.6 & 47.5 & 0.88 & 31.6 & 41.0 & 0.79 \\
\hline Non-innov. & 22.8 & 0.0 & - & 24.4 & 0.0 & - \\
\hline \multicolumn{7}{|l|}{ NACE : } \\
\hline FOOD & 23.5 & 12.1 & 0.13 & 28.5 & 21.1 & 0.46 \\
\hline TEXTILE & 39.9 & 41.4 & 0.68 & 38.5 & 30.2 & 0.68 \\
\hline WOOD & 18.2 & 26.2 & 0.88 & 21.4 & 21.8 & 0.43 \\
\hline CHEM. & 41.0 & 43.9 & 0.91 & 28.7 & 27.8 & 0.56 \\
\hline PLASTIC & 26.7 & 21.5 & 0.65 & 29.5 & 44.4 & 0.98 \\
\hline NON-MET & 19.4 & 13.7 & 0.70 & 25.6 & 37.5 & 0.94 \\
\hline METALS & 22.6 & 26.3 & 0.79 & 24.9 & 31.2 & 0.58 \\
\hline M\&E & 46.8 & 60.2 & 0.98 & 45.4 & 64.5 & 0.99 \\
\hline ELECTRIC & 41.9 & 44.8 & 0.77 & 42.0 & 49.6 & 0.92 \\
\hline VEHIC & 46.8 & 79.9 & 0.98 & 23.9 & 21.1 & 0.87 \\
\hline NEC & 22.5 & 25.9 & 0.70 & 30.7 & 24.4 & 0.52 \\
\hline
\end{tabular}


Table 9

Comparison of innovativeness in Denmark and Ireland: predicted conditional means of the share in sales of new products, CIS I microaggregated data, 1992

\begin{tabular}{|c|c|c|c|c|}
\hline & \multicolumn{2}{|c|}{$\begin{array}{c}\text { Predicted conditional means with } \\
\text { estimates from Denmark }\end{array}$} & \multicolumn{2}{c|}{$\begin{array}{c}\text { Predicted conditional means with } \\
\text { estimates from Ireland }\end{array}$} \\
\hline & \multicolumn{3}{|c|}{ Average share in sales of new products in \% } \\
\hline & Denmark & Ireland & Denmark & Ireland \\
\hline All firms & 32.3 & 30.4 & 33.3 & 31.1 \\
\hline Innovators & 35.6 & 31.8 & 35.9 & 31.6 \\
\hline Non-innov. & 22.8 & 25.8 & 25.4 & 24.4 \\
\hline NACE : & \multicolumn{5}{|c|}{} \\
\hline FOOD & 23.5 & 26.0 & 28.0 & 28.5 \\
\hline TEXTILE & 39.9 & 42.8 & 40.2 & 38.5 \\
\hline WOOD & 18.2 & 18.8 & 18.2 & 21.4 \\
\hline CHEM. & 41.0 & 36.1 & 35.8 & 28.7 \\
\hline PLASTIC & 26.7 & 24.7 & 30.1 & 29.5 \\
\hline NON-MET & 19.4 & 21.1 & 24.6 & 25.6 \\
\hline METALS & 22.6 & 19.8 & 26.1 & 24.9 \\
\hline M\&E & 46.8 & 37.9 & 53.7 & 45.4 \\
\hline ELECTRIC & 41.9 & 43.6 & 40.2 & 42.0 \\
\hline VEHIC & 46.8 & 39.6 & 33.7 & 23.9 \\
\hline NEC & 22.5 & 23.4 & 29.1 & 30.7 \\
\hline
\end{tabular}


Appendix

Industry definitions

\begin{tabular}{|c|c|c|}
\hline $\begin{array}{l}\text { Industry } \\
\text { Abbreviation }\end{array}$ & $\begin{array}{l}\text { NACE } \\
\text { code } \\
(\text { rev.1) }\end{array}$ & Industry definition \\
\hline FOOD & $15-16$ & manufacture of food, beverages and tobacco \\
\hline TEXTILE & $17-19$ & $\begin{array}{l}\text { manufacture of textiles, wearing apparel, dressing and dyeing of } \\
\text { fur, tannings and dressing of leather, luggage, handbags, saddlery, } \\
\text { harness and footwear }\end{array}$ \\
\hline WOOD & $20-22$ & $\begin{array}{l}\text { manufacture of wood and products of wood and cork, except } \\
\text { furniture, manufacture of straw and plaiting materials, pulp, } \\
\text { paper, and paper products, publishing, printing, and reproduction } \\
\text { of recorded media }\end{array}$ \\
\hline CHEM & $23-24$ & $\begin{array}{l}\text { manufacture of coke, refined petroleum products and nuclear fuel, } \\
\text { manufacture of chemicals and chemical products }\end{array}$ \\
\hline PLASTIC & 25 & manufacture of rubber and plastic products \\
\hline NON-MET & 26 & manufacture of other non-metallic mineral products \\
\hline METAL & $27-28$ & $\begin{array}{l}\text { manufacture of basic metals, fabricated metal products, except } \\
\text { machinery and equipment }\end{array}$ \\
\hline$M \& E$ & 29 & manufacture of machinery and equipment NEC \\
\hline ELEC & $30-33$ & $\begin{array}{l}\text { manufacture of office machinery and computers, electrical } \\
\text { machinery and apparatus, radio, television and communication } \\
\text { equipment and apparatus, medical, precision and optical } \\
\text { instruments, watches and clocks }\end{array}$ \\
\hline VEHIC & $34-35$ & $\begin{array}{l}\text { manufacture of motor vehicles, trailers, semi-trailers, and other } \\
\text { transport equipment }\end{array}$ \\
\hline NEC & 36 & manufacture of furniture, manufacturing NEC \\
\hline
\end{tabular}




\section{Liste des publications au CIRANO *}

\section{Cahiers CIRANO / CIRANO Papers (ISSN 1198-8169)}

99c-1 Les Expos, l'OSM, les universités, les hôpitaux : Le coût d'un déficit de 400000 emplois au Québec — Expos, Montréal Symphony Orchestra, Universities, Hospitals: The Cost of a 400,000-Job Shortfall in Québec / Marcel Boyer

96c-1 Peut-on créer des emplois en réglementant le temps de travail? / Robert Lacroix

95c-2 Anomalies de marché et sélection des titres au Canada / Richard Guay, Jean-François L'Her et Jean-Marc Suret

95c-1 La réglementation incitative / Marcel Boyer

94c-3 L'importance relative des gouvernements : causes, conséquences et organisations alternative / Claude Montmarquette

94c-2 Commercial Bankruptcy and Financial Reorganization in Canada / Jocelyn Martel

94c-1 Faire ou faire faire : La perspective de l'économie des organisations / Michel Patry

Série Scientifique / Scientific Series (ISSN 1198-8177)

2000s-19 Rolling-Sample Volatility Estimators : Some New Theoretical, Simulation and Empirical Results / Elena Andreou et Eric Ghysels

2000s-18 Confidence Regions for Calibrated Parameters in Computable General Equilibrium Models / Touhami Abdelkhalek et Jean-Marie Dufour

2000s-17 Markovian Processes, Two-Sided Autoregressions and Finite-Sample Inference for Stationary and Nonstationary Autoregressive Processes / Jean-Marie Dufour et Oliver Torrès

2000s-16 Exact Tests for Contemporaneous Correlation of Disturbances in Seemingly Unrelated Regressions / Jean-Marie Dufour et Lynda Khalaf

2000s-15 Simulation Based Finite and Large Sample Tests in Multivariate Regressions / Jean-Marie Dufour et Lynda Khalaf

2000s-14 Les obstacles à l'innovation dans les industries de services au Canada / Pierre Mohnen et Julio Rosa

2000s-13 Finite Sample Inference Methods for Simultaneous Equations and Models with Unobserved and Generated Regressors / Jean-Marie Dufour et Joanna Jasiak

2000s-12 Protection, Lobbying, and Market Structures / Arye Hillman, Ngo Van Long et Antoine Soubeyrand

2000s-11 The Asian Financial Crisis: The Role of Derivative Securities Trading and Foreign Investors / Eric Ghysels et Junghoon Seon

2000s-10 Productivity Trends and Employment across Industries in Canada / Pierre Mohnen et Thijs ten Raa

\footnotetext{
* Vous pouvez consulter la liste complète des publications du CIRANO et les publications elles-mêmes sur notre site
} Internet à l'adresse suivante :

http://www.cirano.umontreal.ca/publication/documents.html 